\title{
Avaliação da cobertura vacinal do sarampo no período de 2013-2019 e sua relação com a reemergência no Brasil
}

\author{
Evaluation of measles vaccination coverage in the period 2013-2019 and its relationship \\ with reemergence in Brazil
}
Evaluación de la cobertura de vacunación contra el sarampión en el período 2013-2019 y su relación con el resurgimiento en Brasil

Elem Cristina Rodrigues Chaves ${ }^{1}$, Kleber das Neves Trindade Júnior ${ }^{1}$, Beatriz Fernanda Fernandes de Andrade ${ }^{1}$, Maria Helena Rodrigues de Mendonça ${ }^{1}$.

\section{RESUMO}

Objetivo: Avaliar a cobertura vacinal do sarampo nas regiões do Brasil no período 2013 a 2019, e relacionar com sua reemergência no período de 2018 a 2019. Métodos: Trata-se de um estudo ecológico, transversal de caráter descritivo, abrangendo uma análise de séries temporais da cobertura vacinal para tríplice e tetra viral do Brasil. Resultados: Após análise dos dados, foi observado reemergência do sarampo no período de 2017 a 2019, confirmado mais de 10 mil casos de 2018 a 2019, sendo esses concentrados na faixa etária menor de 5 anos seguido de 20 a 29 anos. Tal fato decorre das baixas coberturas vacinais em crianças de 1 a 4 anos, sendo, de acordo com os dados, menores que a meta estabelecida pelo Ministério da Saúde para todas as regiões do Brasil, o qual favorece o atual perfil de surto de alguns estados, como Pará, São Paulo e Rio de Janeiro. Conclusão: As baixas coberturas vacinais influenciam diretamente no aumento dos casos de doenças imunopreveníveis, tais coberturas inadequadas decorrem da crescente desinformação da população referente às vacinas e seus benefícios. Destaca a importância das avaliações constantes das coberturas vacinais e fortalecimento dos sistemas de vigilância epidemiológica.

Palavras-chave: Vacina tríplice, Sarampo, Cobertura vacinal.

\begin{abstract}
Objective: To evaluate the vaccination coverage of measles in the regions of Brazil in the period 2013 to 2019 , and to relate with its reemergence in the period from 2018 to 2019. Methods: This is an ecological, crosssectional descriptive study, covering a time series analysis of the vaccine coverage for threefold and tetra viral in Brazil. Results: After data analysis, measles reemergence was observed in the period from 2017 to 2019, confirming more than 10000 cases from 2018 to 2019, being those concentrated in the age group under 5 years, followed by 20 to 29 years. This fact stems from the low vaccination coverage in children aged 1 to 4 years, and, according to the data, lower than the goal established by the Ministry of Health for all regions of Brazil, which favors the current outbreak profile of some states, such as Pará, São Paulo and Rio de Janeiro. Conclusion: Low vaccine coverage directly influences the increase in cases of immunopreventable diseases, such inadequate coverage is due to the increasing disinformation of the population regarding vaccines and their benefits. It highlights the importance of the assessments of vaccine coverage and the strengthening of epidemiological surveillance systems.
\end{abstract}

Keywords: Triple vaccine, Measles, Vaccination coverage.

\footnotetext{
${ }^{1}$ Faculdade Integrada Brasil Amazônia (FIBRA), Belém-PA. *E-mail: elemcrc@gmail.com
} 


\section{RESUMEN}

Objetivo: Evaluar la cobertura de vacunación contra el sarampión en las regiones de Brasil en el período 2013-2019, y relacionarse con su reaparición en el período de 2018 a 2019. Métodos: Este es un estudio descriptivo ecológico y transversal, que abarca un análisis en serie temporal de la cobertura de la vacuna para tres veces y tetra viral en Brasil. Resultados: Después del análisis de datos, se observó un resurgimiento del sarampión en el período comprendido entre 2017 y 2019, confirmando más de 10000 casos de 2018 a 2019 , siendo los concentrados en el grupo de edad menor de 5 años, seguido de 20 a 29 años. Este hecho se deriva de la baja cobertura de vacunación en niños de 1 a 4 años, y, según los datos, inferior al objetivo establecido por el Ministerio de Salud para todas las regiones del Brasil, lo que favorece el perfil de brote actual de algunos Estados , como Pará, Sao Paulo y Río de Janeiro. Conclusión: La baja cobertura de vacunas influye directamente en el aumento de los casos de enfermedades inmunoprevenibles, esta cobertura inadecuada se debe a la creciente desinformación de la población con respecto a las vacunas y sus beneficios. Destaca la importancia de las evaluaciones de la cobertura de vacunas y el fortalecimiento de los sistemas de vigilancia epidemiológica.

Palabras clave: Vacuna triple, Sarampión, Cobertura de vacunación.

\section{INTRODUÇÃO}

Desde que Edward Jenner demonstrou que a imunização poderia ser alcançada e assim diminuir as mortes causadas por doenças transmissíveis, a sociedades humana investe nas melhorias ou descobertas de novas vacinas (LOROCCA LM e CARRARO TE, 2000). No século XVIII, a varíola foi considerada uma das principais patologias que dizimaram a população mundial, em 1980, a Organização Mundial de Saúde (OMS) conseguiu sua erradicação após vacinação em massa (BRASIL, 2005).

No Brasil, o Programa Nacional de Imunização (PNI), criado em 1973 pelo Ministério da Saúde (MS), tem como objetivo coordenar as ações de imunizações administradas rotineiramente nos serviços de saúde, tentar alcançar as coberturas vacinais e erradicar ou controlar diversas doenças imunopreveníveis, representando um avanço de extrema importância para saúde pública, tal programa conta com a respeitabilidade e credibilidade da população e de grupos científico (MONTEIRO CN, et al., 2018; MIZUTA AH, et al., 2019).

Apesar do seu reconhecido impacto na diminuição da morbimortalidade de doenças infectocontagiosas, evitando milhões de mortes, a aceitação das vacinas ainda não é universal (MIZUTA AH, et al., 2019). Essa medida preventiva, frequentemente, vem sendo questionada e criticada devido aos seus efeitos adversos (WHO, 2015).

Os grupos de recusa vacinal ou antivacinismo têm se tornado mais evidente em diversos países, o receio aos Eventos Adversos Pós Vacinação (EAPV) vem se proliferando em todo o mundo, aumentando a quantidade de pessoas e grupos que declaram preocupações com a segurança e a necessidade da aplicação das vacinas (MONTEIRO CN, et al., 2018).

Atualmente, o PNI define um Calendário Nacional de Vacinação que contempla dezessete vacinas distribuídas de forma gratuita pelo Sistema Único de Saúde (SUS) (BRASIL, 2017).

A vacina tríplice viral, incluída no calendário de vacinação em 1992, trata-se de uma vacina atenuada que contém vírus vivo do sarampo, rubéola e caxumba (SRC) sem a capacidade de induzir doenças, sendo administradas e duas doses, a primeira aos doze meses de idade e a segunda aos quinze meses. Tenta-se estabelecer uma ampla imunização de rotina para que a cobertura vacinal atinja o patamar de 95\% (BRASIL, 2014; CVE, 2016; SBIM, 2017). A tríplice viral é altamente imunogênica, conferindo proteção de $98 \%$ contra sarampo, 99,3\% contra rubéola e 96,1\% contra caxumba (SVS, 2018).

O sarampo, rubéola e caxumba, são doenças altamente contagiosas e de fácil propagação com predomínio durante a infância, sua transmissão ocorre por vias aéreas através de tosse e espirros ou contato 
com a saliva e secreções respiratórias de indivíduos infectados, tais patologias são capazes de apresentar várias complicações graves (BRASIL, 2003; CVE, 2017). Não há tratamento específico para tais infecções, baseia-se na realização de medidas de suporte e utilização de medicamentos sintomáticos, e a melhor forma de prevenção é através da vacinação (TAVARES W e MARINHO LAC 2005; BRASIL, 2019).

Em 2013, a vacina tetra viral (tríplice viral + varicela) foi introduzida ao calendário de vacinação substituindo a segunda dose da tríplice viral para crianças de quinze meses. A vacina foi introduzida com o objetivo de evitar complicações e óbitos por varicela e controlar e eliminar doenças preveníveis pela tríplice viral (BRASIL, 2014). Embora as vacinas estejam disponíveis nos serviços públicos de saúde e sua eficácia seja comprovada, a circulação de informações sem comprovação científica, a exemplo da pesquisa publicada pelo médico Andrew Wakefield, o qual associava a utilização da tríplice viral ao autismo, fazem com que a procura pela vacina diminua, mantendo a cobertura vacinal abaixo da meta, tornando assim, possível a circulação viral (WAKEFIELD AJ, 1999; BRASIL, 2005).

Segundo a OMS, nos últimos anos, casos de sarampo têm sido registrados em diversas partes do mundo. Até os três primeiros meses de 2019 , os números de casos notificados cresceram cerca de $300 \%$ (OMS, 2019).

Brasil registrou, em 2015, os últimos casos de sarampo, no ano seguinte, recebeu o certificado de eliminação da circulação do vírus, no entanto, o país corre o risco de perder tal reconhecimento devido às dificuldades em interromper a transmissão dos surtos ocorridos desde 2017 (BRASIL, 2018).

A continuidade de determinado agente viral na população humana, deriva do quantitativo de pessoas vulneráveis imunologicamente, sendo a vacinação a única forma de prevenir e diminuir as possíveis reintroduções virais. Portanto, são necessárias avaliações epidemiológicas ativas (notificação de casos suspeitos em 24 horas, investigação ágil, avaliações constantes das coberturas vacinais e surtos) para desenvolver estratégias que visem à melhoria e ampliação das medidas de prevenção e controle. Visto isso, é necessária uma boa investigação epidemiológica e manutenção do sistema de vigilância para essas doenças.

O presente estudo tem como objetivo avaliar a cobertura vacinal do sarampo nas regiões do Brasil no período 2013 a 2019, identificando os estados que apresentaram baixa cobertura vacinal e relacionar com sua reemergência no período de 2018 a 2019.

\section{MÉTODOS}

Trata-se de um estudo ecológico de aspecto transversal, caráter descritivo com abordagem quantitativa, abrangendo uma análise de séries temporais da cobertura vacinal para tríplice e tetra viral nas regiões do Brasil no período de 2013 a 18/04/2019. Os dados referentes à cobertura vacinal foram extraídos do Sistema de Informação do Programa Nacional de Imunizações (SI-PNI), a partir do registro dos imunos aplicados e do quantitativo populacional vacinado no período estudado. Os dados alusivos aos casos de sarampo foram coletados através de notas informativas publicadas pelo Ministério da Saúde (MS) referente ao monitoramento do período sazonal do sarampo no Brasil, segundo faixa etária, no período de Fevereiro de 2018 a 28 de Junho de 2019 (Figura 1).

Para revisão da literatura, foi utilizado bases de dados online como Scientific Electronic Library Online (SciELO), Sistema Online de Busca e Análise de Literatura Médica (MEDLINE), Pan American Health Organization (PAHO), com os seguintes descritores: sarampo, cobertura vacinal e vacina tríplice e, além disso, foram utilizadas informações advindas de boletins epidemiológicos e informes técnicos publicados pelo MS, relatórios e livros.

Para tabulação de dados da pesquisa e elaboração de tabelas e gráficos, foi utilizado o editor de planilha Microsoft Office Excel plataforma x86 (2016) e o programa GraphPadPrism 6.7. O registro dos dados baseouse na percentagem das coberturas vacinais de cada região do Brasil por Unidade Federativa (UF) e total de casos confirmado de sarampo no período estudado, caracterizando o perfil da cobertura vacinal (Figura 1). 
Figura 1 - Organograma metodológico referente às aquisições das informações e análises dos dados do artigo.

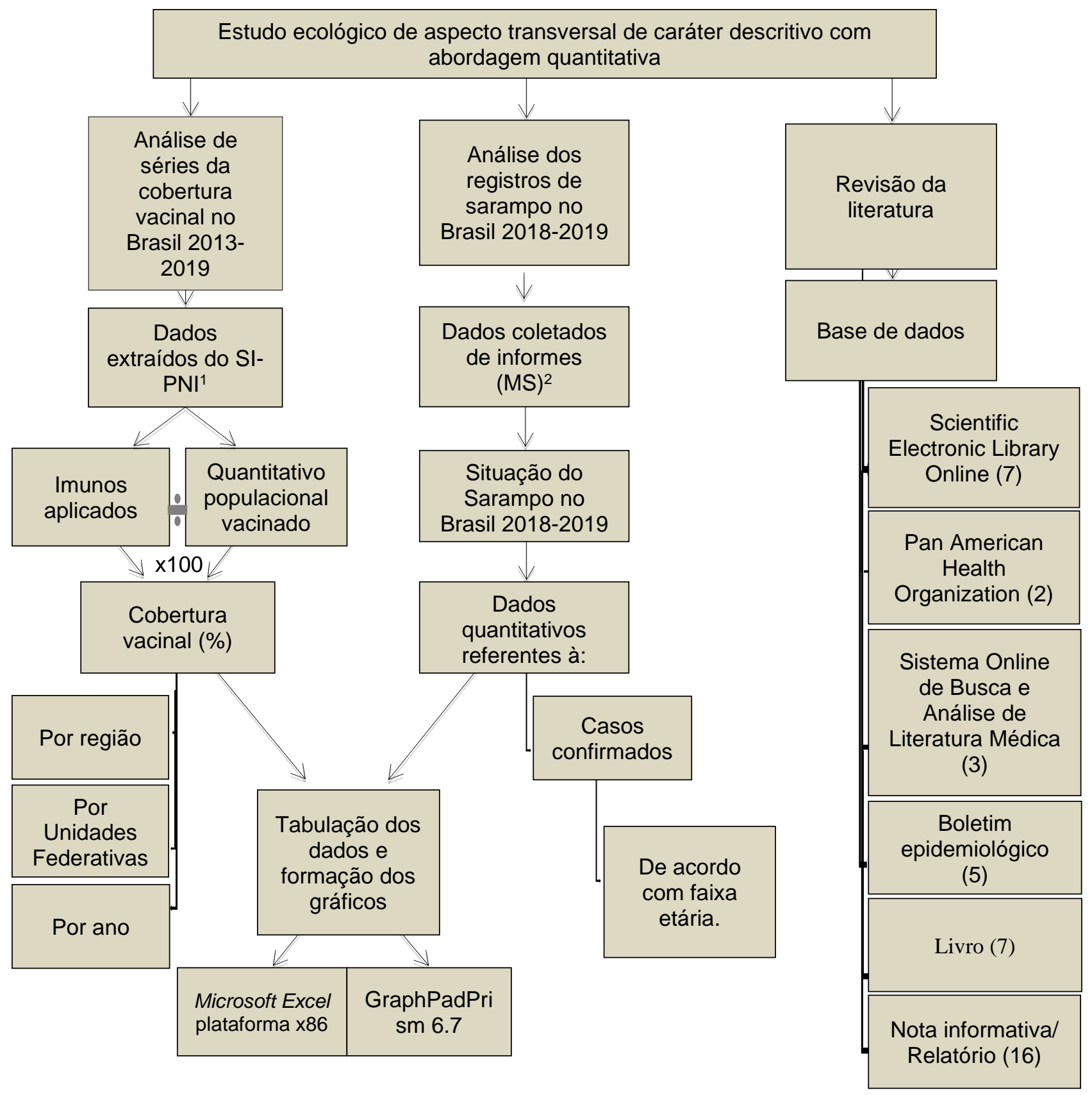

Legenda: ${ }^{1}$ Sistema de Informação do Programa Nacional de Imunizações. ${ }^{2}$ Ministério da Saúde.

Fonte: Chaves ECR, et al., 2019.

\section{RESULTADOS E DISCUSSÃO}

Desde 2015 sem registrar casos de sarampo, sendo os últimos ocorridos no estado do Ceará, São Paulo e Roraima, o Brasil, a partir de 2017, vem enfrentando uma reemergência viral devido, principalmente, as baixas coberturas vacinais. No período de 2017 a 2018, de acordo com Informe No 17|2017/2018 foram confirmados 1.100 casos de sarampo no Brasil.

Após esse período, segundo dados obtidos pelo Informe № 37 e 42 | 2018/2019, no período de Fevereiro de 2018 a 28 de Junho de 2019, foram confirmados 10498 casos de sarampo, desses, os maiores número 
foram registrados nos estados de Amazonas com 93,47\%, Roraima 3,45 \% e Pará com 1,50\%, seguidos de São Paulo $(0,66 \%)$, Rio Grande do Sul $(0,44 \%)$, Rio de Janeiro $(0,30 \%)$, Pernambuco $(0,04 \%)$, Sergipe $(0,04 \%)$, Bahia $(0,03 \%)$, Rondônia $(0,02 \%)$, Distrito Federal $(0,01 \%)$, Minas Gerais $(0,04 \%)$ e Santa Cataria $(0,03 \%)$. Atualmente, o estado do Pará, São Paulo e Rio de Janeiro, encontram-se em situação de surto ativo, as demais unidades federativas (UF), tiveram seus últimos registros no período de Julho de 2018 a Março de 2019 (Tabela 1).

Tabela 1- Representa a frequência de casos confirmados de Sarampo por Unidades Federativas seguido de seus últimos registros no período de 06 de Fevereiro de 2018 a 28 de Junho de 2019 no Brasil.

\begin{tabular}{|c|c|c|c|}
\hline \multirow{2}{*}{$\mathrm{UF}^{1}$} & \multicolumn{3}{|c|}{ 2018/2019* } \\
\hline & $\mathbf{N}$ & $\%$ & Último resgistro \\
\hline Amazonas & 9.812 & 93,47 & $31 / 01 / 2019$ \\
\hline Roraima & 362 & 3,45 & 06/02/2019 \\
\hline Pará** & 157 & 1,50 & 05/05/2019 \\
\hline São Paulo** & 69 & 0,66 & $25 / 05 / 2019$ \\
\hline Rio Grande do Sul & 46 & 0,44 & $14 / 09 / 2018$ \\
\hline Rio de Janeiro** & 31 & 0,30 & $14 / 05 / 2019$ \\
\hline Pernambuco & 4 & 0,04 & $30 / 07 / 2018$ \\
\hline Sergipe & 4 & 0,04 & $27 / 08 / 2018$ \\
\hline Bahia & 3 & 0,03 & $23 / 09 / 2018$ \\
\hline Rondônia & 2 & 0,02 & $11 / 07 / 2018$ \\
\hline Distrito Federal & 1 & 0,01 & $26 / 07 / 2018$ \\
\hline Minas Gerais & 4 & 0,04 & 06/03/2019 \\
\hline Santa Catarina & 3 & 0,03 & $18 / 02 / 2019$ \\
\hline Total & 10498 & & \\
\hline
\end{tabular}

Legenda: ${ }^{1}$ Unidades Federativas. ${ }^{*}$ Dados atualizados em 28/06/2019 e sujeitos a alterações. ${ }^{* *}$ Estados com surto ativo.

Fonte: INFORME № 37| 2018/2019; INFORME № 42| 2019.

Segundo Tarifa JR e Armani G (2001), todas as estações do ano constituem um importante fator na propagação de doenças, no entanto, baseado em padrões climáticos, o outono (Março a Junho) favorece tal transmissão, pois ocasiona declínio das temperaturas, com isso, há tendência da população aglomerar-se em ambientes fechados, contribuindo para disseminação do sarampo, visto que sua transmissão ocorre através de gotículas no ar. De acordo com Informe $N^{\circ} 42$ | 2019, seguindo a curva epidêmica dos casos notificados, as UF em condição de surto ativo registraram picos de casos no final de Fevereiro a Maio, coincidindo com o aumento da suscetibilidade da população no período do outono.

No período estudado, todos os casos confirmados são de origem brasileira, exceto em Roraima que, dos 362 casos registrados, 219 eram venezuelanos, um Guiana e um da Argentina. Desde 2017 a Venezuela passa por surtos de sarampo e, com a atual crise sociopolítica-econômica, provoca migração para outros 
países em busca de proteção. Informações do governo brasileiro e o Alto Comissariado das Nações Unidas para Refugiados (2018), demonstram que cerca de 32.744 venezuelanos requereram refúgio no país e 27.804 obtiveram autorização por vias alternativas.

A fronteira entre Roraima e Venezuela apresenta-se como principal forma de entrada dos imigrantes, o estado detém a menor população e a menor participação no Produto Interno Bruto (PIB) (ITAÚ, 2018). Com isso, estado não possui condições adequadas para recepcionar um contingente grande de imigrantes, nem tampouco assegurar à atenção primária básica a saúde, a exemplo, imunização dos imigrantes. De acordo com OMS (2019), o genótipo encontrado no Brasil refere-se ao D8, o mesmo circulante na Venezuela, esses dados ratificam que os casos são importados devido ao intenso movimento migratório.

Em uma análise da distribuição de casos confirmados segundo faixa etária, todas as faixas apresentaram casos. No estado do Amazonas, os casos concentram-se em menores de cinco anos com $28,34 \%$, seguido de 20 a 29 anos com aproximadamente $25 \%$. Referente ao estado de Roraima, desconsiderando a nacionalidade, $51,52 \%$ apresentam-se em menores de cinco anos; Pará, maiores casos em menores de cinco anos (39,49\%) seguido de 20 a 29 (15,29\%); São Paulo, concentrou-se na faixa de 20 a 39 (63,77\%); no Rio de Janeiro, com casos distribuídos em menores de um ano, de 1 a 4, 10 a 19, 20 a 29 e maiores de 50 anos, tendo predominância em menores de um ano com $36,36 \%$ dos caso, os demais estados não foram identificados faixa etária (Tabela 2).

Tabela 2 - Demonstra a distribuição de casos confirmados de Sarampo segundo faixa etária, registrados no Brasil por Unidades Federativas no período de Fevereiro de 2018 a 28 de Junho de 2019.

\begin{tabular}{|c|c|c|c|c|c|c|c|c|c|c|}
\hline \multirow[b]{2}{*}{ Faixa Etária } & \multicolumn{10}{|c|}{ 2018/2019* } \\
\hline & Amazonas & $\%$ & Roraima & $\%$ & Pará & $\%$ & $\begin{array}{c}\text { São } \\
\text { Paulo** }\end{array}$ & $\%$ & $\begin{array}{c}\text { Rio de } \\
\text { Janeiro** }\end{array}$ & $\%$ \\
\hline$<1$ ano & 1699 & 17.32 & 85 & 23.55 & 32 & 20.38 & 7 & 10.14 & 4 & 36.36 \\
\hline 1 a 4 & 1081 & 11.02 & 101 & 27.98 & 30 & 19.11 & 4 & 5.80 & 1 & 9.09 \\
\hline 5 a 9 & 423 & 4.31 & 55 & 15.24 & 15 & 9.55 & 1 & 1.45 & 1 & 9.09 \\
\hline 10 a 14 & 465 & 4.74 & 36 & 9.97 & 13 & 8.28 & 2 & 2.90 & 1 & 9.09 \\
\hline 15 a 19 & 2075 & 21.16 & 25 & 6.93 & 22 & 14.01 & 2 & 2.90 & 0 & - \\
\hline 20 a 29 & 2451 & 24.99 & 35 & 9.70 & 24 & 15.29 & 31 & 44.93 & 2 & 18.18 \\
\hline 30 a 39 & 1010 & 10.30 & 16 & 4.43 & 12 & 7.64 & 13 & 18.84 & 0 & - \\
\hline 40 a 49 & 423 & 4.31 & 7 & 1.94 & 5 & 3.18 & 7 & 10.14 & 0 & - \\
\hline$>50$ anos & 181 & 1.85 & 1 & 0.28 & 4 & 2.55 & 2 & 2.90 & 2 & 18.18 \\
\hline
\end{tabular}

Legenda: *Dados atualizados em 28/06/2019 e sujeitos a alterações. ${ }^{* *}$ Estados com surto ativo.

Fonte: INFORME № 37| 2018/2019; INFORME № 42| 2019.

De acordo com os dados, observa-se predominância de casos tanto em crianças, como jovens e adultos, destacando a importância da imunização em todas as faixas etárias, onde, sem a devida vacinação, estão propícios a contrair qualquer doença imunoprevenível. A tríplice viral é administrada em duas doses, a partir de um ano de idade, no entanto, devido aumento de casos na faixa etária não atingida pela vacinação, o MS amplia a faixa e estabelece que crianças a partir de seis meses devem ser imunizadas com "dose zero". 
Dados divulgados pelo MS (2019) informam quatro óbitos em decorrência da doença, todos sem imunização comprovada, desses, três ocorreram em crianças menores de um ano. Fatos esses corroboram a necessidade da vacinação em públicos mais susceptíveis a casos graves e a óbitos.

Em locais onde há ocorrência de casos de sarampo, as ações de vacinação com objetivo de interromper a transmissão tem sido intensa, no entanto, mesmo com esse perfil de surto, as coberturas vacinais para tríplice e tetra viral permanecem abaixo da meta (BRASIL, 2019). Segundo MS (2015), cobertura vacinal para primeira dose (D1) é referente às doses aplicadas em crianças de 12 meses, com relação à segunda dose (D2), soma-se as segundas doses da tríplice e a dose da tetra viral para crianças de 15 meses.

Ao analisar a cobertura vacinal de 2013 a Abril de 2019, foi observada que, para primeira dose da tríplice (D1), todas as regiões apresentaram um decréscimo da cobertura a partir de 2017, no entanto, a região Norte apresenta diminuição desde 2015. Os estados do Amazonas, Roraima e Pará, em comparação a São Paulo e Rio de Janeiro, apresentam os maiores números de casos na faixa etária atingida pela vacinação, de 1 a 4 anos, com $11,02 \%, 27,98 \%$ e $15,24 \%$ dos casos, respectivamente. Em uma análise percentual das coberturas vacinais para esses estados, Amazonas e Roraima apresentam-se abaixo da meta de $95 \%$ desde 2016, o estado do Pará, a partir de 2015 demonstra oscilação da cobertura entre $69 \%$ a $75 \%$ e, mesmo com perfil de surto ativo, atingiu 54\% das coberturas em Abril de 2019 (Gráfico 1).

Com relação a D2, todas as regiões apresentam coberturas muito abaixo da meta, tal fato demonstra o maior percentual de casos na faixa menor de 5 anos, uma vez que as coberturas não estão sendo realizadas de maneira adequada nessa população. O estado de São Paulo e Rio de Janeiro, os quais demonstraram uma cobertura adequada no período de 2013 a 2018 para D1, demonstram baixa cobertura para D2 a partir de 2015 (Gráfico 2). Esses dados ratificam o motivo pelo qual percentual de casos na faixa de 1 a 4 é de $5,8 \%$ em São Paulo e 9,09\% para Rio de Janeiro, pois a D1 está sendo realizados, entretanto, sem a completude das doses, esses indivíduos permanecem susceptíveis e, com isso, mantem a circulação do vírus e seu atual cenário de surto.

A partir de 2013, a vacina Tetra Viral surge como substituta da D2 ou um reforço para crianças de 15 meses com vacinação comprovada, contudo, apresenta um padrão mais baixo para todas as regiões quando comparado a D2 (Gráfico 3). 
Gráfico 1 - Demonstra a cobertura vacinal para tríplice viral, primeira dose (D1).

A

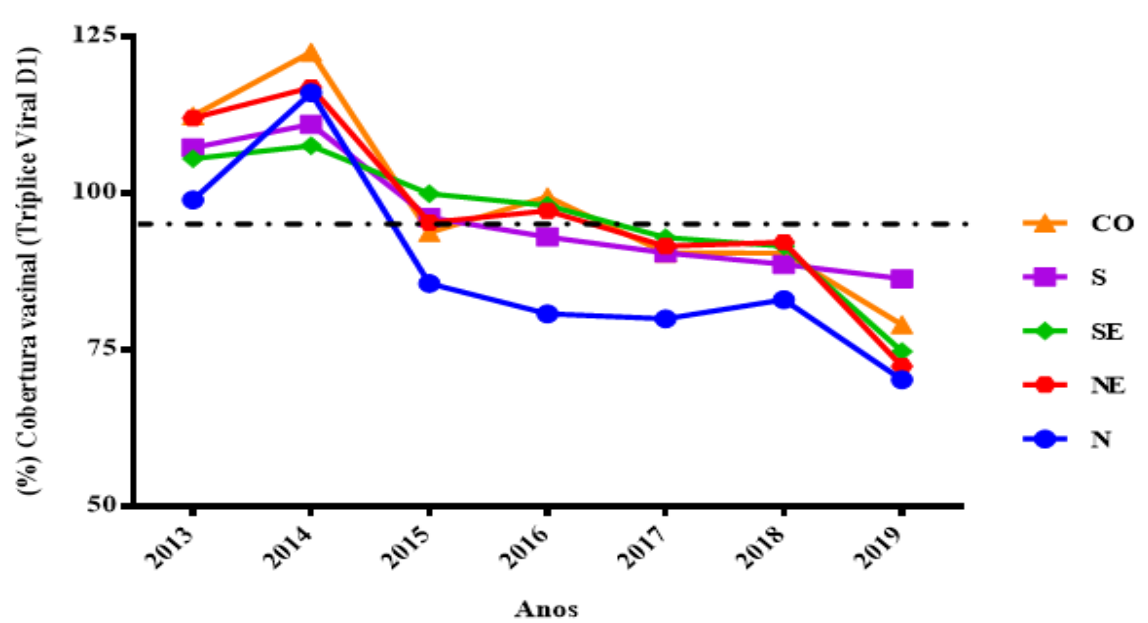

c

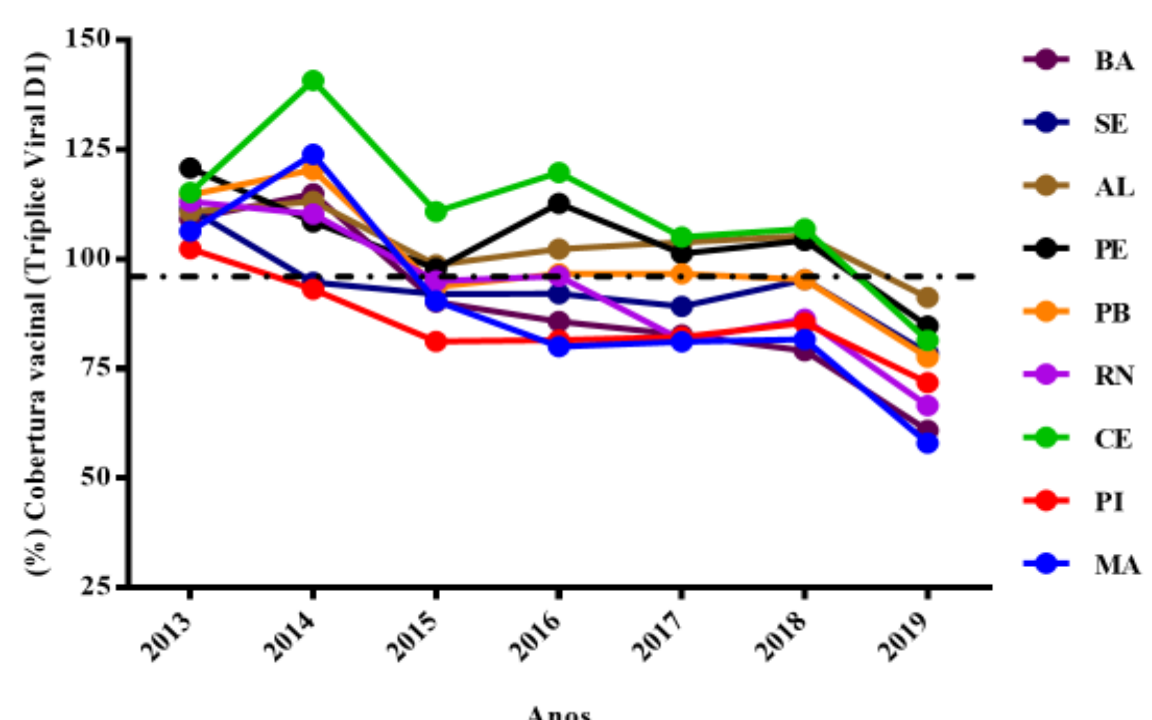

B

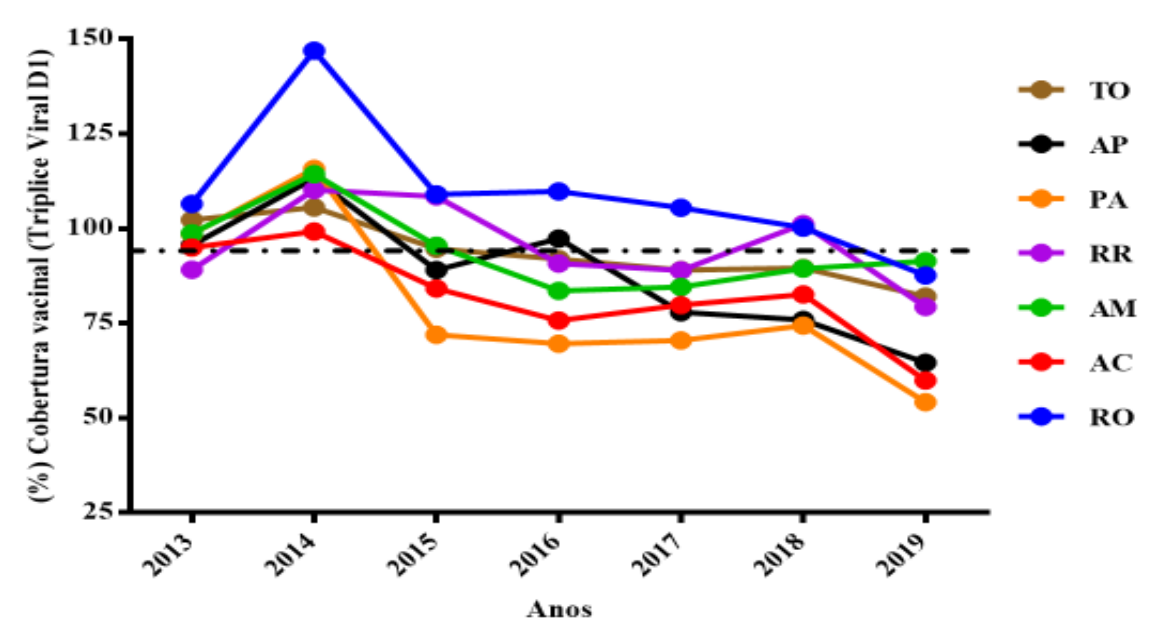

D

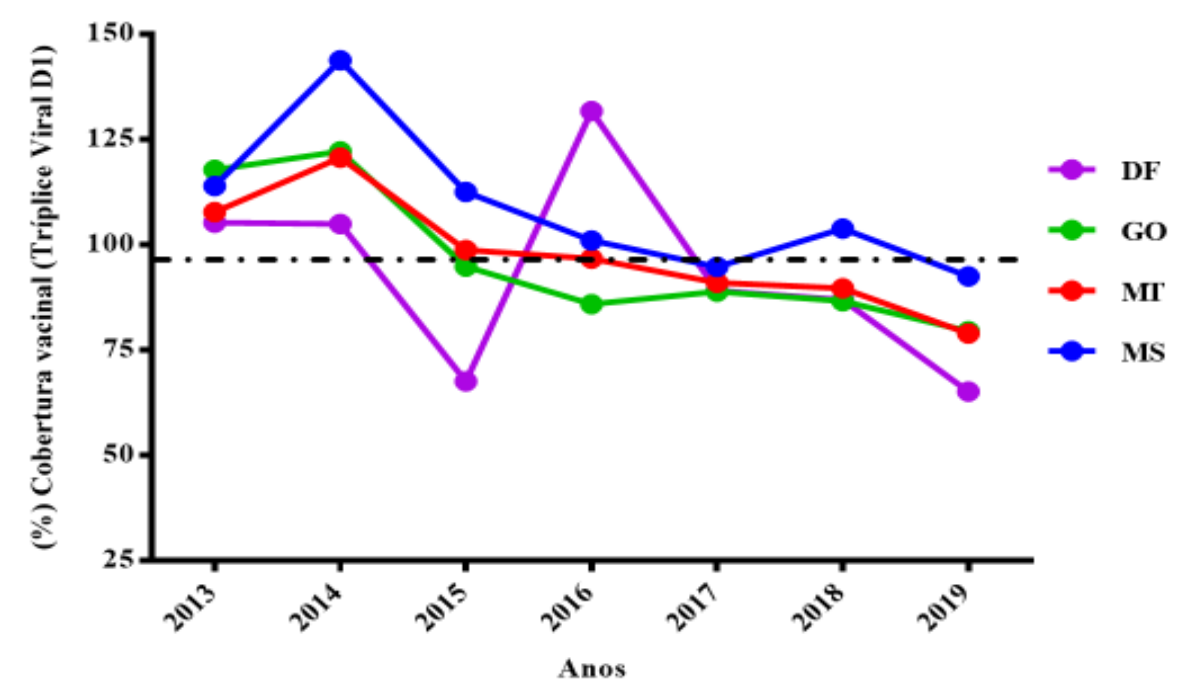


E

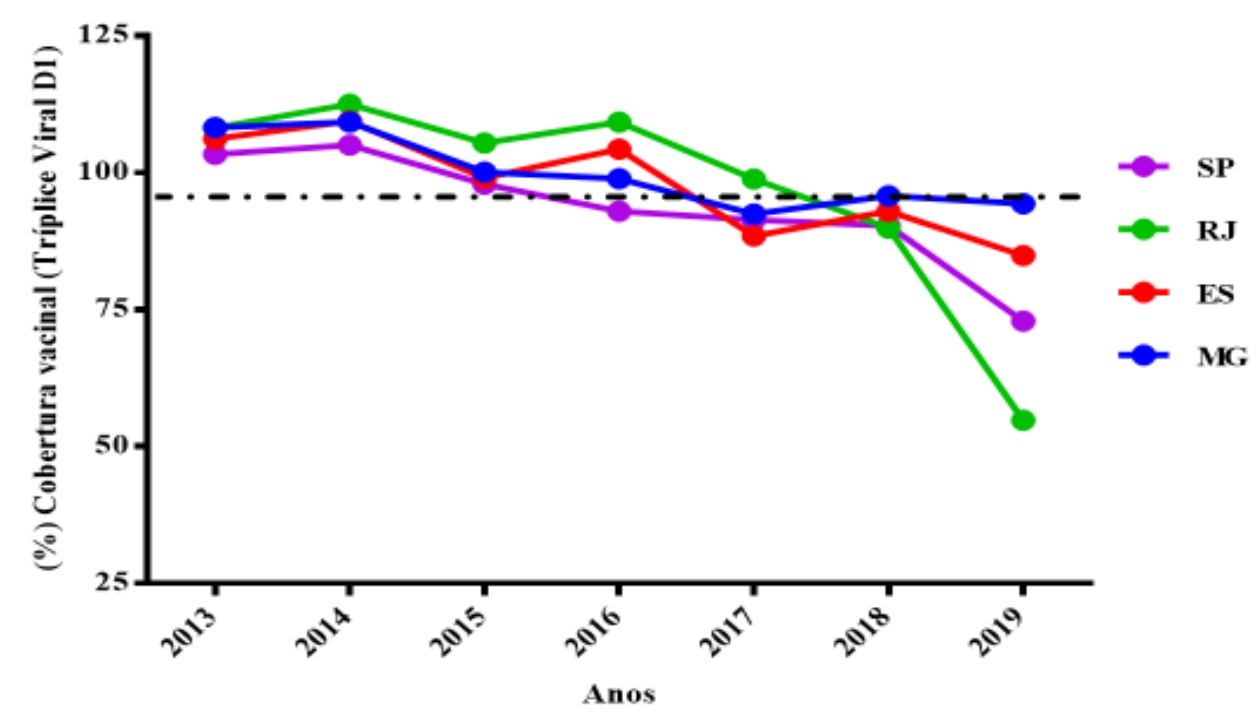

$\mathbf{F}$

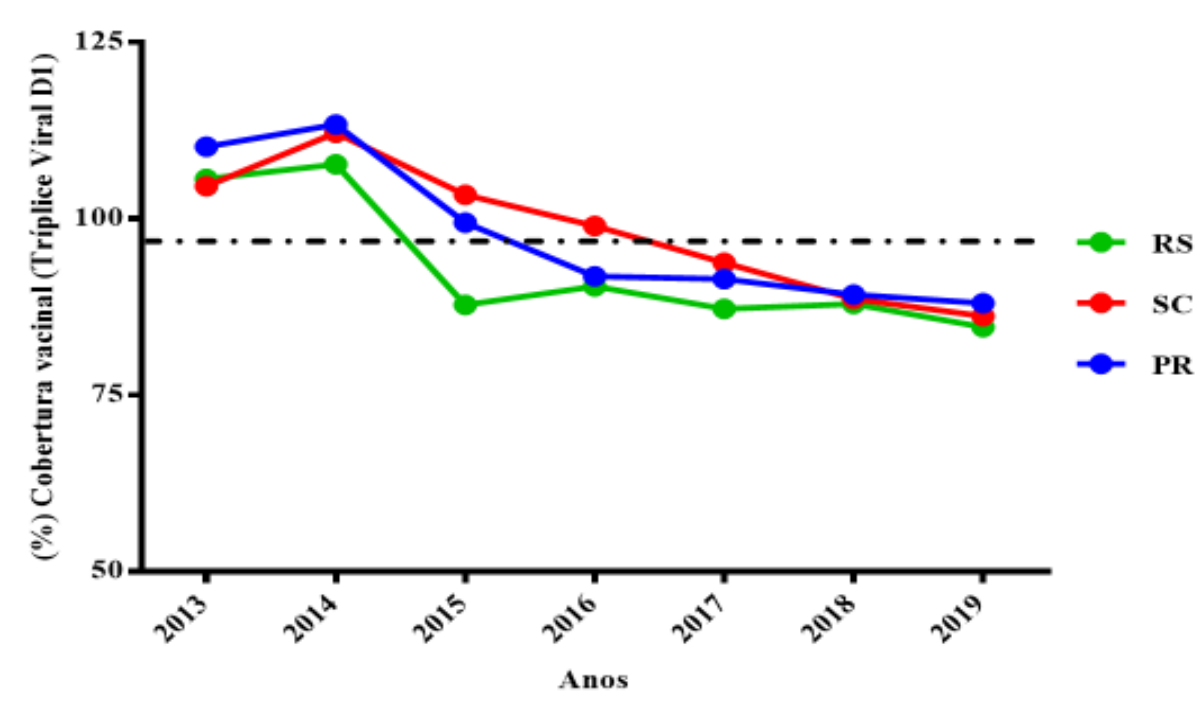

Legenda: A: Cobertura para todas as regiões do Brasil no período de 2013 a abril de 2019; B: Cobertura de cada Unidade Federativa (UF) da região Norte (N); C; Cobertura de cada UF da região Nordeste (NE); D: Cobertura de cada UF da região Centro Oeste (CO); E: Cobertura de cada UF da região Sudeste (SE); F: Cobertura de cada UF da região Sul (S).

Fonte: Dados do SINAN. Dados atualizados em 18/04/2019 e sujeitos a alterações. 
Gráfico 2 - Demonstra a cobertura vacinal para tríplice viral, segunda dose (D2).

A

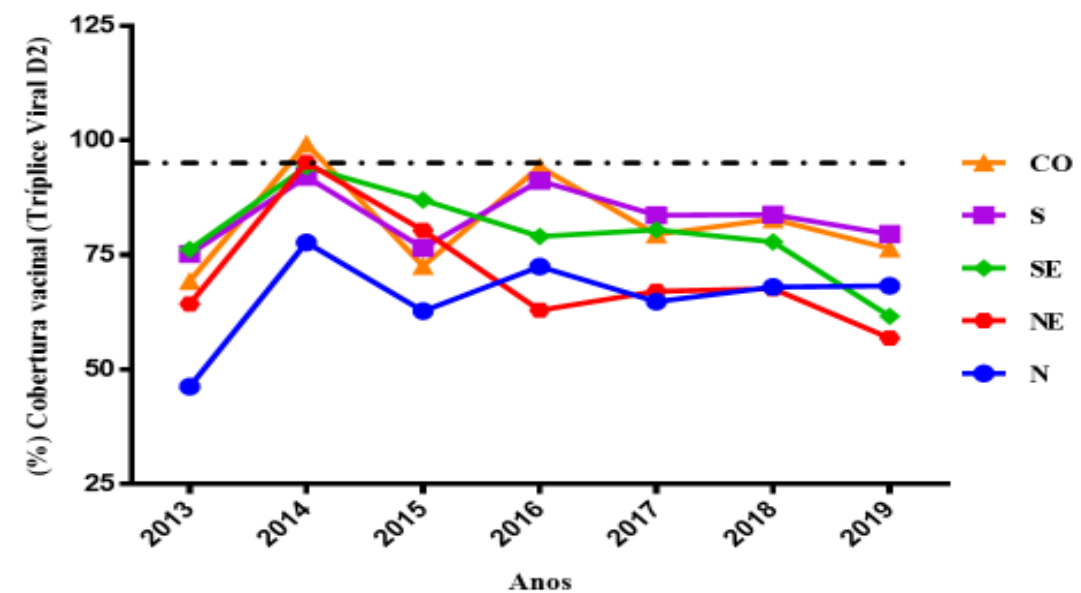

C

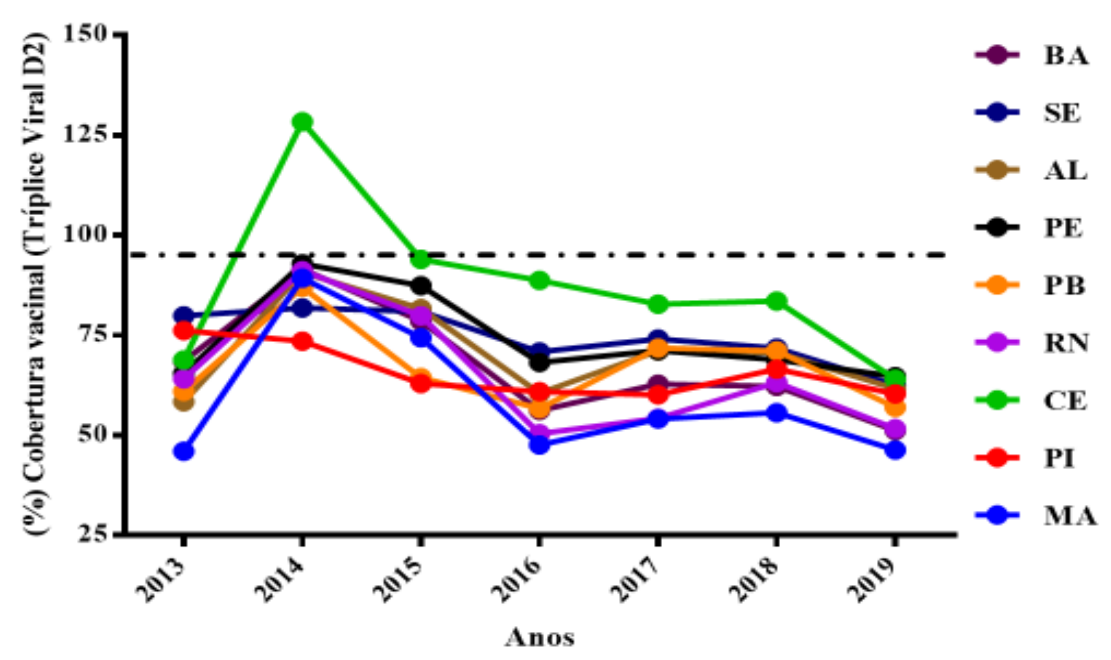

B

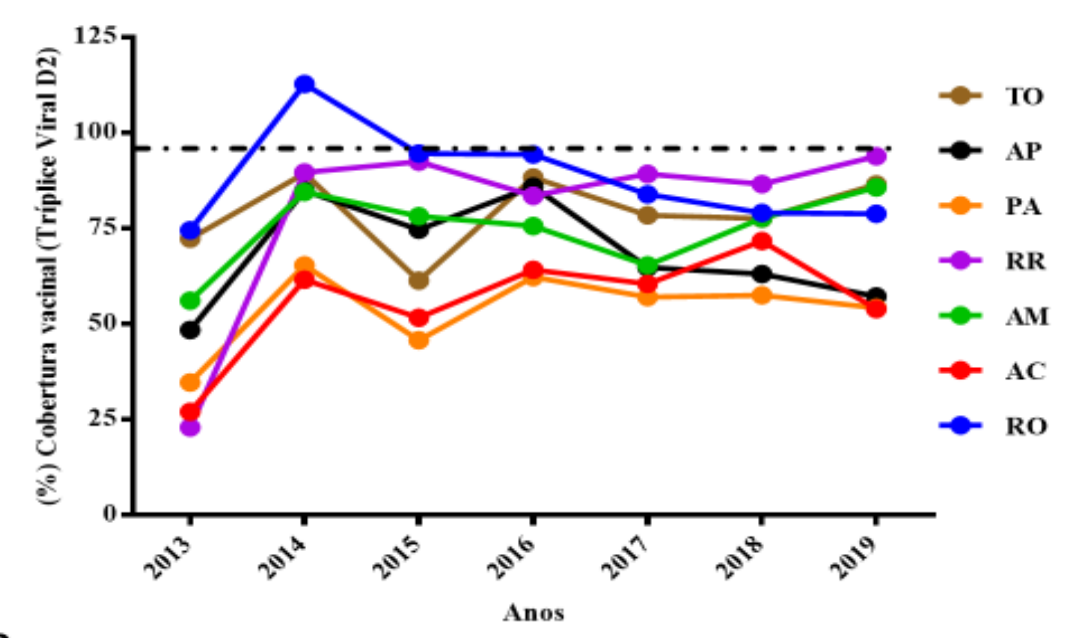

D

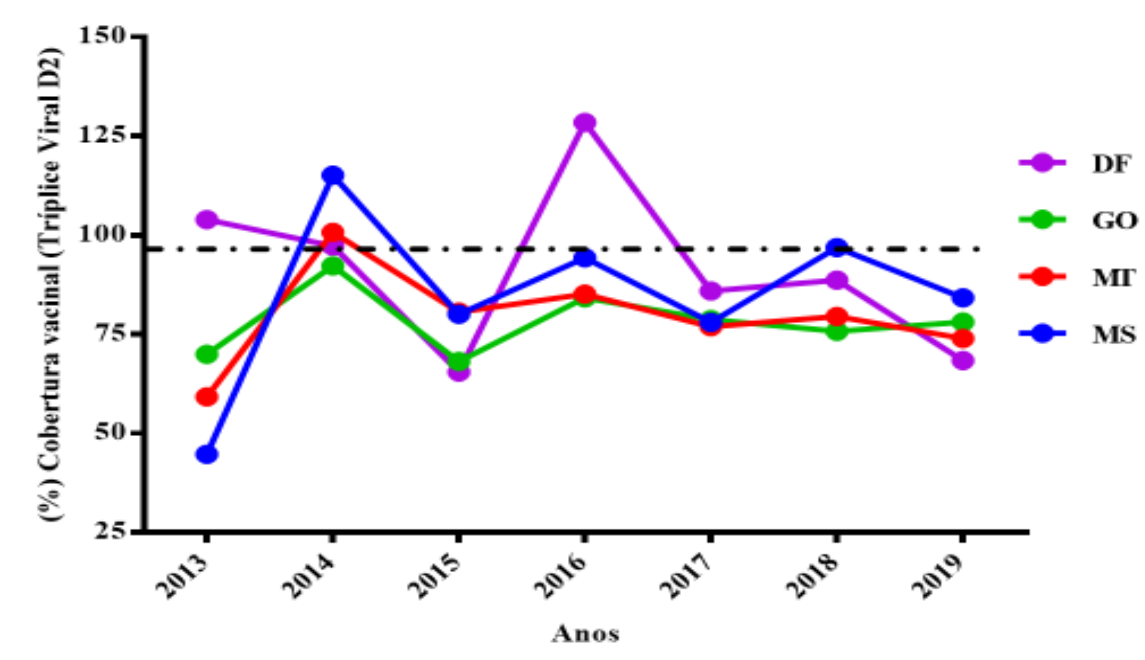


E

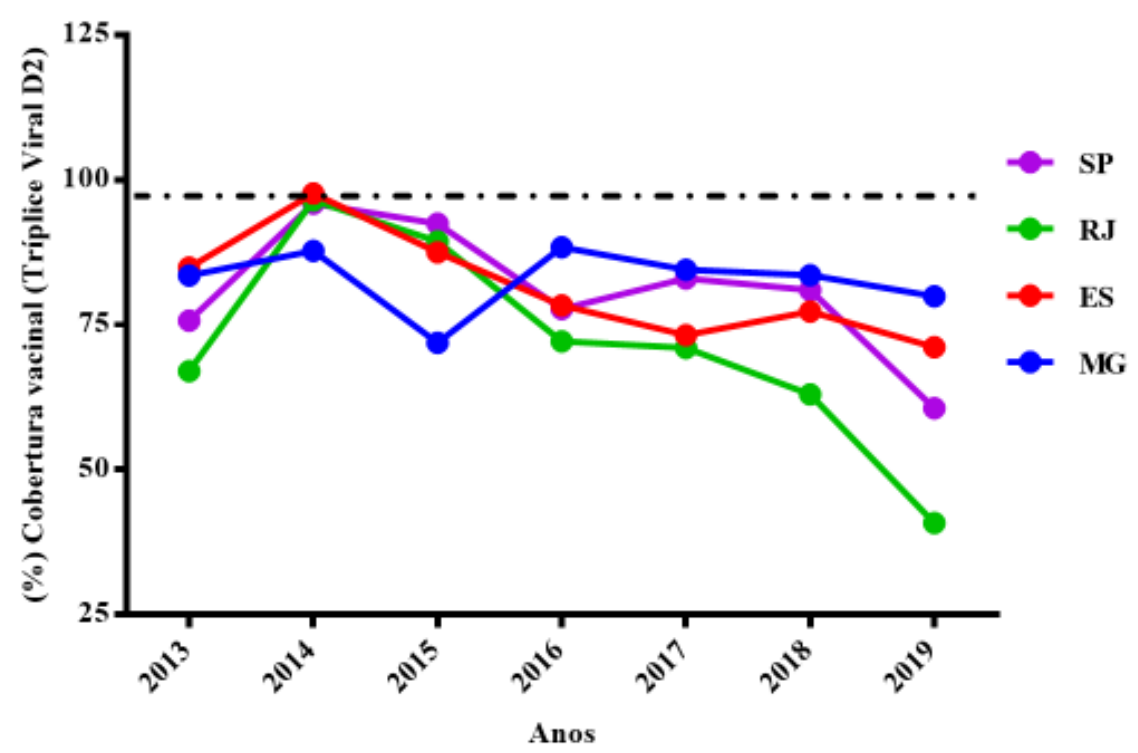

$\mathbf{F}$

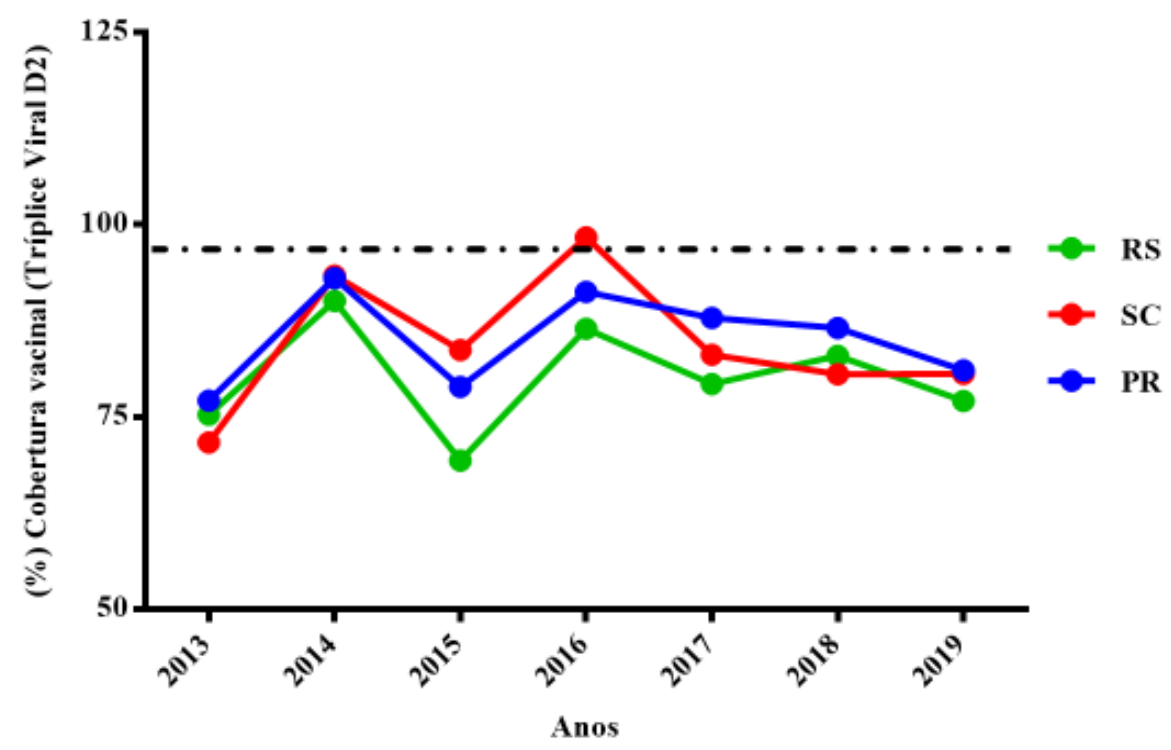

Legenda: A: Cobertura para todas as regiões do Brasil no período de 2013 a abril de 2019; B: Cobertura de cada Unidade Federativa (UF) da região Norte (N); C; Cobertura de cada UF da região Nordeste (NE); D: Cobertura de cada UF da região Centro Oeste (CO); E: Cobertura de cada UF da região Sudeste (SE); F: Cobertura de cada UF da região Sul (S).

Fonte: Dados do SINAN. Dados atualizados em 18/04/2019 e sujeitos a alterações. 
Gráfico 3 - Demonstra a cobertura vacinal para tetra viral.

A

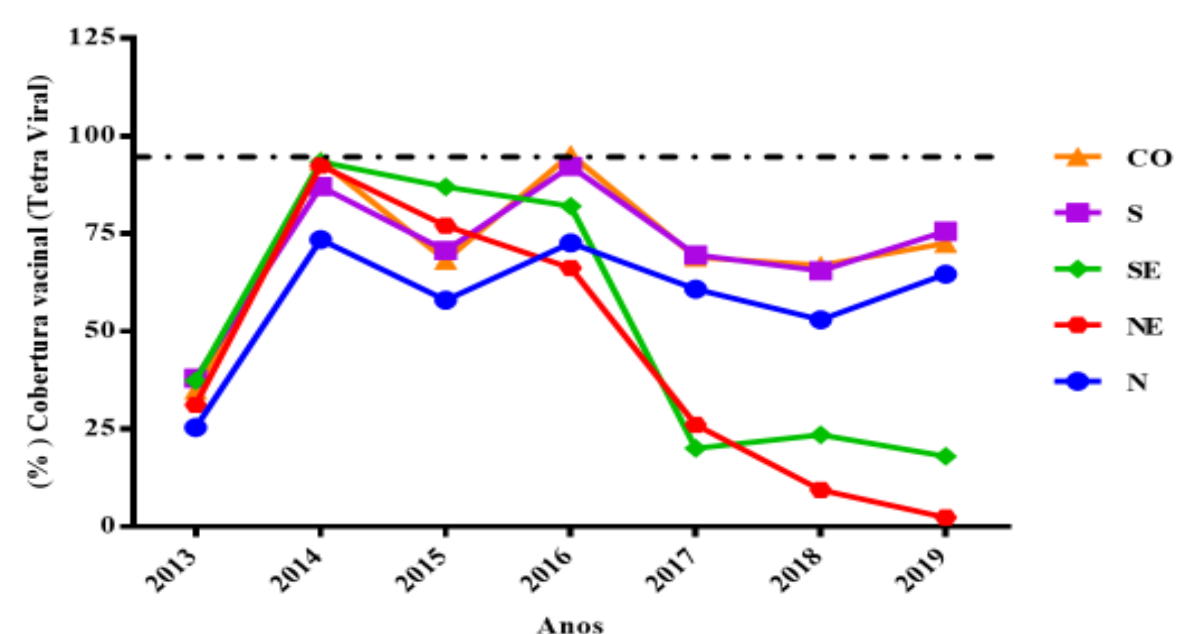

c

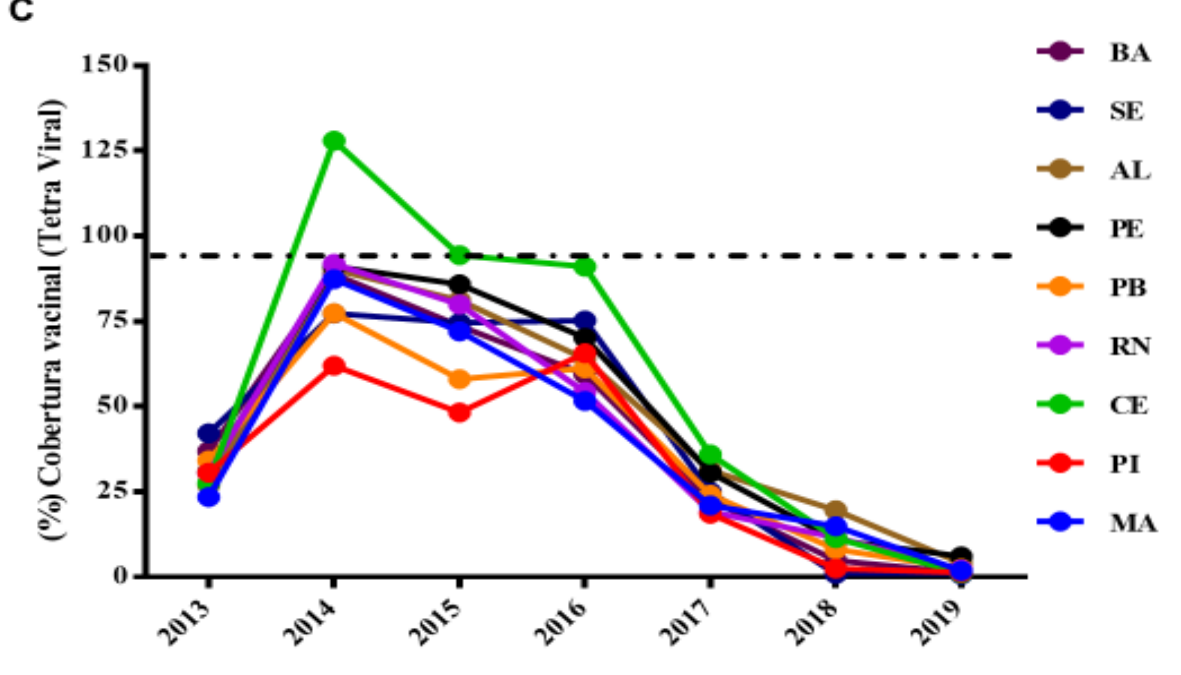

B

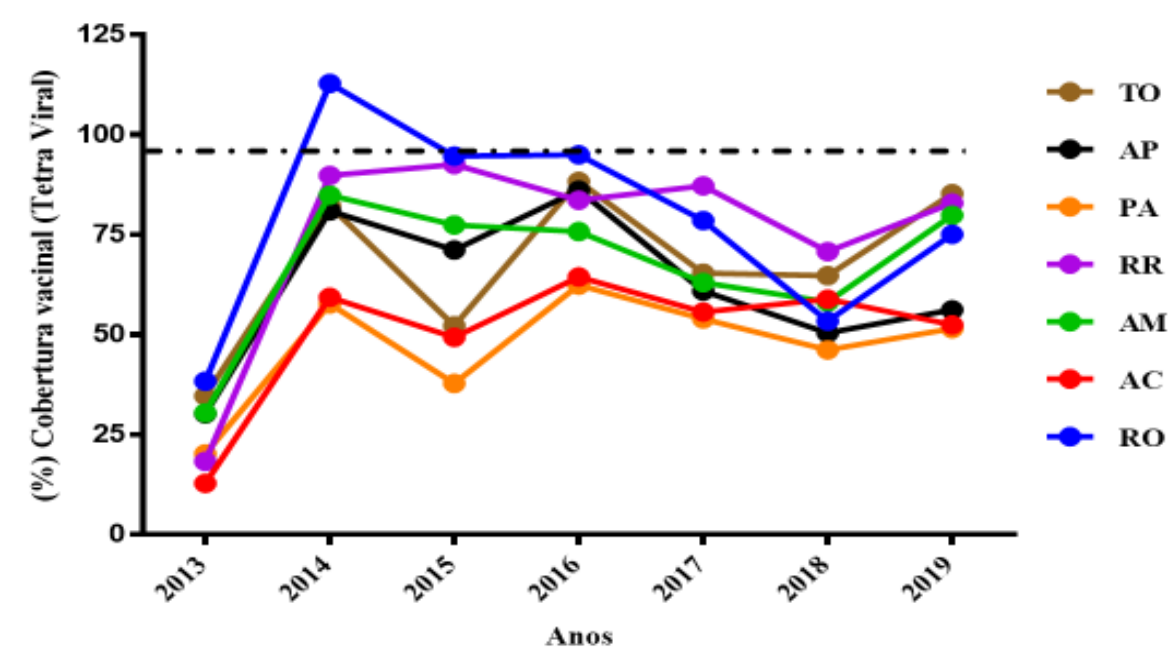

D

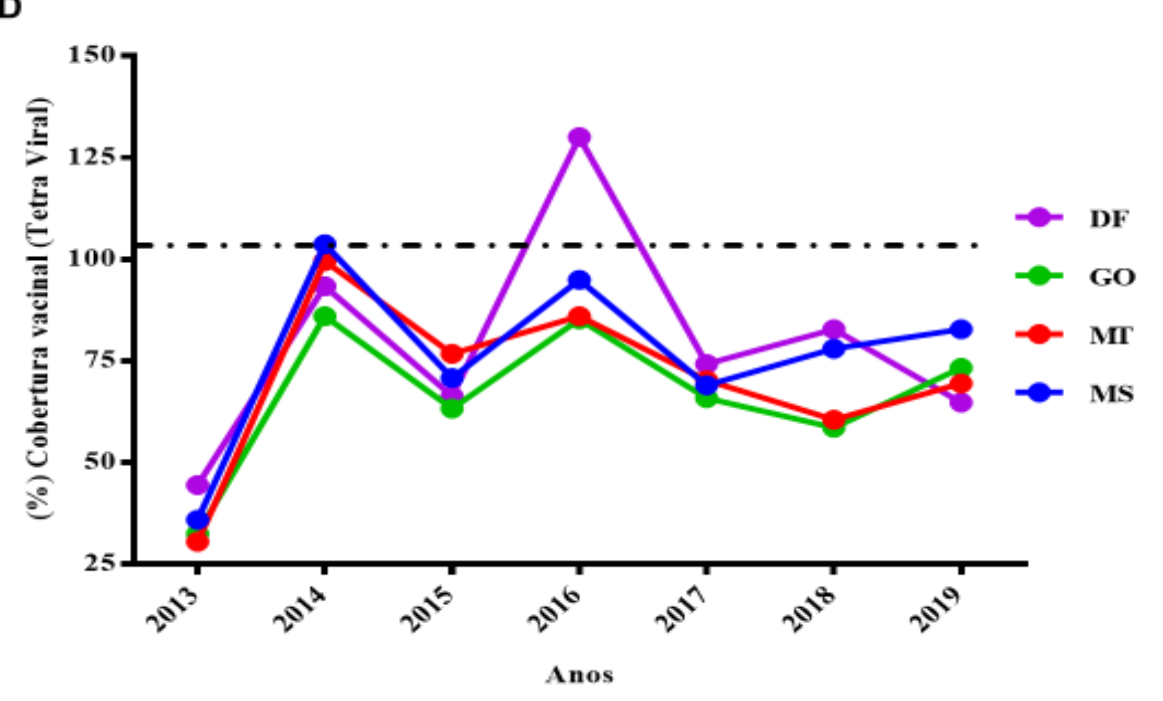

$\overline{\text { REAS/EJCH | Vol.Sup.n.38 | e1982 | DOI: https://doi.org/10.25248/reas.e1982.2020 Página } 12 \text { de } 16}$ 
E

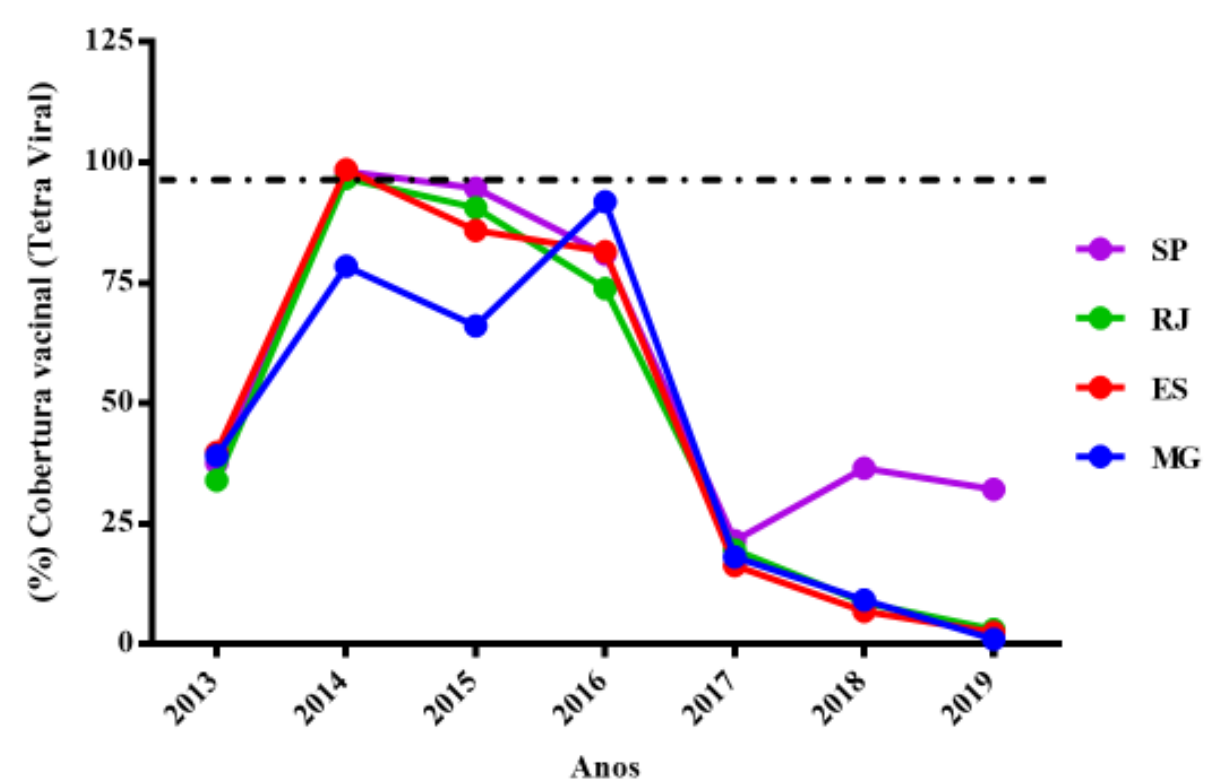

$\mathbf{F}$

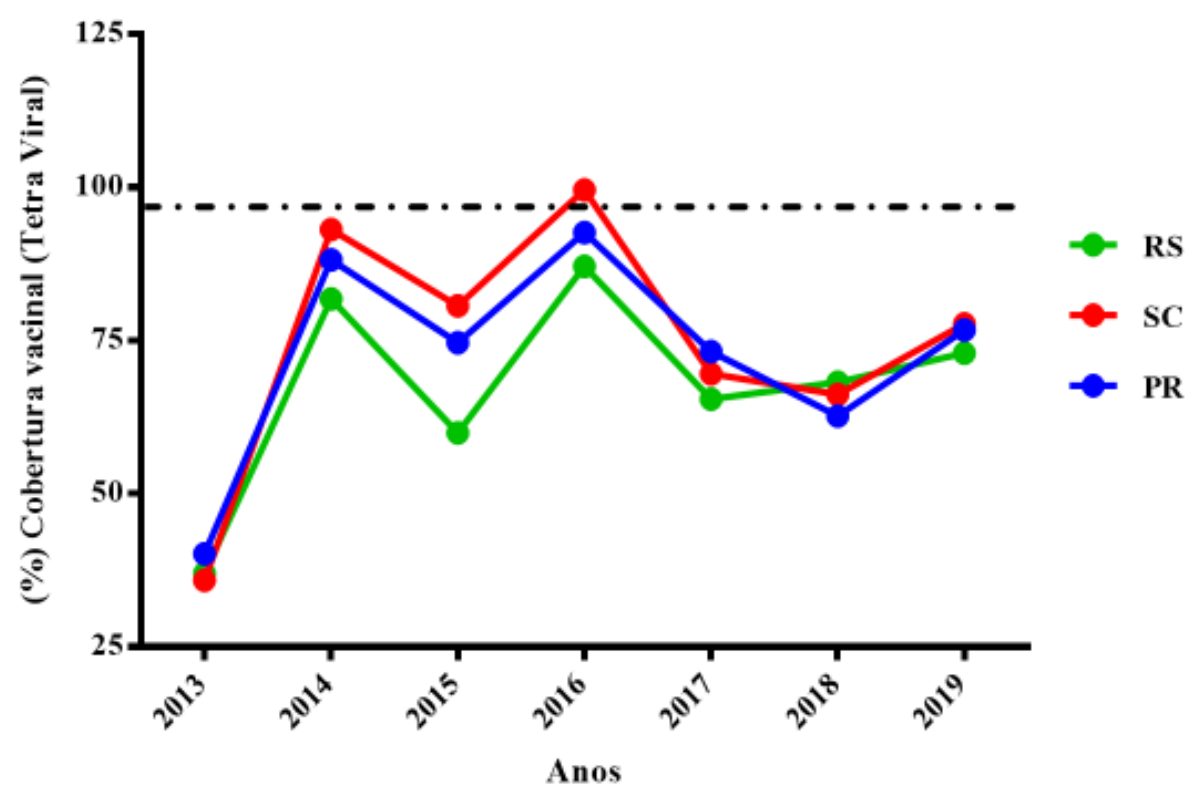

Legenda: A: Cobertura para todas as regiões do Brasil no período de 2013 a abril de 2019; B: Cobertura de cada Unidade Federativa (UF) da região Norte (N); C; Cobertura de cada UF da região Nordeste (NE); D: Cobertura de cada UF da região Centro Oeste (CO); E: Cobertura de cada UF da região Sudeste (SE); F: Cobertura de cada UF da região Sul (S).

Fonte: Dados do SINAN. Dados atualizados em 18/04/2019 e sujeitos a alterações. 
A imunização não é limitada ao público infantil, todavia, é foco para garantir uma barreira de proteção com intuito de conter o vírus. De acordo com os boletins epidemiológicos, a segunda maior faixa etária acometida pela doença é adulta de 20 a 29 anos. A prevenção da faixa de 1 a 5 anos, baseia-se na imunização coletiva, a qual confere resistência a um determinado grupo à disseminação do vírus, aonde pessoas vulneráveis, como os menores de um ano e de 20 a 29 anos, se beneficiam dessa condição, contribuindo para o controle de doenças infectocontagiosas, porém, a baixa imunização de rotina favorece a reemergência viral.

Os benefícios coletivos e individuais advindos da imunização são originados de um elevado empenho, custos financeiros e grandes estruturas de autoridades sanitárias com finalidade de garantir segurança das vacinas, no entanto, mesmo com sua eficácia comprovada, grupos de recusa vacinal reconhecem as vacinas como insegura e desnecessária. Tal fato não é recente, no Reino Unido, no século XIX, por exemplo, havia charges contra vacina da varíola (DUBÉ E, et al., 2015).

De acordo com a OMS (2019), desde 2013 o país vem registrando queda das coberturas vacinais. Doenças consideradas erradicadas, como a poliomielite, são ameaças à população devido ao descaso com a medida de prevenção (OMS, 2019). Atualmente, o cenário de surto ativo de sarampo, considerada erradicada, e as baixas coberturas vacinais para todas as regiões, demonstram a enorme influencia dos grupos de recusa ao país.

As vacinas, assim como outros produtos biológicos, podem trazer efeitos adversos ao indivíduo, efeitos consideravelmente menores aos quais produzidos pela doença que objetiva proteger e, junto a isso, determinantes de recusa, como fatores socioculturais e pessoais, as crenças e argumentos de grupos antivacinas, sendo esses divulgados principalmente através das mídias sociais, devido ao rápido mecanismo de disseminação e a superficialidade de conteúdo, influenciam na confiabilidade e aceitação das vacinas criando bolsões de indivíduos suscetíveis e, em um grupo desse perfil, apenas uma pessoa infectada poderá causar surtos de grandes proporções (MACDONALD ME, 2015; SUCCI RCM, 2018). Com isso, o principal desafio para o país é manter as taxas de coberturas vacinais altas a fim de controlar e prevenir epidemias.

De acordo com MacDonald ME (2015) a aceitação representa um mecanismo complexo de decisão influenciado por diversos fatores, considera-se a o modelo dos 3Cs; Confiança (credibilidade), Complacência (baixo risco) e Conveniência (disponibilidade). Não é correto definir a recusa como um processo dividido em dois polos (recusa e aceitação) uma vez que incide de uma série de eventos sequenciais entre as duas situações, os que aceitam ou recusam todas e os que aceitam umas e recusam outras.

Atualmente, vacinas como da poliomielite, febre amarela, meningocócica $C$ e entre outras, encontram-se abaixo da média nacional de cobertura (BRASIL, 2018). A maneira pela qual as informações se disseminam cresceu de forma relevante no sentido à velocidade, a veiculação rápida na mídia interativa de notícias relacionando a vacinação com complicações graves, a exemplo da associação da tríplice viral com autismo e meningites assépticas, informações essas não comprovadas cientificamente, fazem com que a procura pela vacina diminua (SILVA PRV, et al, 2015).

Outro fator importante é referente à completude do esquema vacinal, o abandono e a desinformação da importância das doses de vacina fazem com que o número de casos de determinada doença aumente, causando surtos no país, uma vez que a imunização completa só será realizada a partir da adesão de todas as doses necessárias (SILVA FSS, et al., 2018). Sendo o sarampo uma doença altamente contagiosa, demonstrando perfil de óbitos e a vacinação sua principal medida de prevenção, o panorama de surto apenas será contido incrementando a cobertura vacinal ideal para evitar circulação do vírus.

\section{CONCLUSÃO}

A vacinação é uma das principais e a mais eficaz medida de prevenção, tendo como objetivo controlar e erradicar doenças infectocontagiosas. No entanto, diversos fatores complexos como religião e socioeconômico, podem contribuir para recusa vacinal, aumentando o número de doenças. Sendo assim, são importantes às avaliações constantes das coberturas vacinais, a fim de manter a continuidade, ampliação da cobertura vacinal e, disponibilizar informações aos gestores de saúde e a população. Esse estudo expõe a 
importância de manter as coberturas vacinais e fortalecer os sistemas de vigilância epidemiológica em diferentes territórios, além de reforçar o monitoramento das fronteiras e ações que visem combater informações sem caráter científico com intuito de controlar doenças e evitar possíveis surtos.

\section{REFERÊNCIAS}

1. CENTRO DE VIGILÂNCIA EPIDEMIOLÓGICA "Prof. Alexandre Vranjac". Norma Técnica do Programa de Imunização. São Paulo: SES-SP. 2016.

2. CENTRO DE VIGILÂNCIA EPIDEMIOLÓGICA "Prof. Alexandre Vranjac". Alerta sobre Sarampo, São Paulo: SESSP. 2017.

3. CENTER FOR CHRONIC DISEASE PREVENTION. Mumps: For Healthcare Providers. 2019.

4. BRASIL. MINISTÉRIO DA SAÚDE. Programa Nacional de Imunizações: Queda nos índices das coberturas vacinais no Brasil. 2018.

5. BRASIL. MINISTÉRIO DA SAÚDE. Programa Nacional de Imunizações: Coberturas vacinais no Brasil Período de 2010 a 2014. 2015.

6. BRASIL. MINISTÉRIO DA SAÚDE Secretaria de Vigilância em Saúde. Manual de Vigilância para Erradicação do Sarampo, Controle da Rubéola e Eliminação da Síndrome da Rubéola Congênita (SRC). 3르 Ed. Brasília-DF. 2003.

7. BRASIL. MINISTÉRIO DA SAÚDE. Programa Nacional de Imunizações (PNI). Manual de Eventos Adversos PósVacina. Brasília (DF). 2005.

8. BRASIL. MINISTÉRIO DA SAÚDE. Manual de normas e procedimentos para vacinação. Brasília: Ministério da Saúde. 2014.

9. BRASIL. MINISTÉRIO DA SAÚDE. Brasil/MS/SVS; Guia de Vigilância em Saúde. Brasília. 2017

10. BRASIL. MINISTÉRIO DA SAÚDE. Folha informativa Nํ17- Sarampo. 2018.

11. BRASIL. MINISTÉRIO DA SAÚDE. Portal da Saúde INFORME № 17/2017-2018.

12. BRASIL. MINISTÉRIO DA SAÚDE. Portal da Saúde INFORME №37/2018-2019.

13. BRASIL. MINISTÉRIO DA SAÚDE. Portal da Saúde INFORME № 42/2019.

14. BRASIL. MINISTÉRIO DA SAÚDE. Blog da Saúde. Coordenadora do Programa Nacional de Imunizações desmente boatos. 2017.

15. BRASIL. MINISTÉRIO DA SAÚDE. Blog da Saúde. Caxumba: o que é, causas, sintomas, tratamento, diagnóstico e prevenção. 2019.

16. BRASIL. MINISTÉRIO DA SAÚDE. Blog da Saúde. Ministro da Saúde defende ampliar cobertura de vacinação como prioridade para o mundo. 2019.

17. DIAS ALP, MITRE EIA. IMUNIZAÇÃO CONTRA A RUBÉOLA NO PRIMEIRO TRIMESTRE DE GESTAÇÃO PODE LEVAR À PERDA AUDITIVA? Rev CEFAC, 2009; v.11, Supl1, 12-17

18. DUBÉ E, et al. Hesitação vacinal, recusa de vacinas e o movimento anti-vacinal: influência, impacto e implicações. RevEspecialista em Vacinas. 2015.

19. ITAÚ. Macrovisão-Índice Itaú de Atividade dos Estados. Relatório. 2018.

20. INTERNATIONAL ORGANIZATION FOR MIGRATION (IOM). Regional Action Plan: Strengthening the regional response to large scale migration of Venezuelan Nationals into South America, North America, Central America and the Caribbean. Relatório. 2018.

21. LOROCCA LM, CARRARO TE. O mundo das vacinas- caminhos (des)conhecidos. Cogitare Enferm., Curitiba, 2000; v.5, n.2, p.43-50.

22. MACDONALD ME. SAGE WORKING GROUP ON VACCINE HESITANCY. Hesitação vacinal: definição, escopo e determinantes. Vacina, 2015; v. 33, Edição 34.

23. MIZUTA AH, et al. Percepções acerca da importância das vacinas e da recusa vacinal numa escola de medicina. Revista Paulista de Pediatria, 2019; v. 37, n. 1, p.34-40.

24. MONTEIRO CN, et al. Cobertura vacinal e utilização do SUS para vacinação contra gripe e pneumonia em adultos e idosos com diabetes autorreferida, no município de São Paulo, 2003, 2008 e 2015. Epidemiologia e Serviços de Saúde., Brasília, 2018; v. 27, n. 2, p.1-8.

25. MORAES MM, et al. Trajetória da rubéola no Estado do Pará, Brasil: rumo à erradicação. Rev. Pan-Amaz. Saude. 2015.

26. MOURA ADA, et al. Monitoramento Rápido de Vacinação na prevenção do sarampo no estado do Ceará, em 2015. Epidemiol. Serv. Saúde, Brasília. 2018.

27. ORGANIZAÇÃO MUNDIAL DA SAÚDE. Folha informativa: Sarampo. 2019.

28. ORGANIZAÇÃO MUNDIAL DA SAÚDE. Plano de ação para assegurar a sustentabilidade da eliminação do sarampo, rubéola e síndrome da rubéola congênita nas Américas 2018-2023. $29^{\circ}$ Conferência Sanitária Pan-americana $69^{\circ}$ Sessão do Comitê Regional da OMS para as Américas. Washington, D.C., EUA. 2017.

29. ORGANIZAÇÃO MUNDIAL DA SAÚDE. Dados de Vigilância de Sarampo. 2019.

30. SILVA FSS, et al. Incompletude vacinal infantil de vacinas novas e antigas e fatores associados: coorte de nascimento BRISA, São Luís, Maranhão, Nordeste do Brasil. Cad. Saúde Pública. 2018.

31. SILVA PRV et al. Sociedade de risco midiatizada, o movimento antivacinação e o risco do autismo. Ciência \& Saúde Coletiva, 2015; 20 (2): 607-616. 
32. SOCIEDADE BRASILEIRA DE IMUNIZAÇÃO (SBIM). Guia de vacinação geriatria sbim/sbgg. 2017.

33. SOCIEDADE BRASILEIRA DE IMUNIZAÇÃO (SBIM) Imunização de Adultos e Idosos - Bases para estudos e decisões. 2018

34. SUCCI RCM. Recusa vacinal - que é preciso saber. J. Pediatr. (Rio J.) vol.94 no.6 Porto Alegre Nov./Dec. 2018.

35. SUPERINTENDÊNCIA DE VIGILÂNCIA EM SAÚDE. Nota Informativa SUVISA n 26/2018. Campanha de vacinação contra poliomielite e sarampo. 2018.

36. TAVARES W, MARINHO LAC. Rotinas de diagnóstico e tratamento das doenças infecciosas e parasitárias. São Paulo: Atheneu. 2005.

37. TARIFA JR, ARMANI G. Os climas urbanos GEOUSP, 2001. World Health Organization.Measles Surveillance. 2012.

38. UNITED NATIONS HIGH COMISSIONER FOR REFUGEES (UNHCR). Venezuela Situation: responding to the need of people displaced from Venezuela. Supplementary Appeal.Relatório. 2018.

39. WAKEFIELD AJ. MMR Vaccination and Autism. The Lancet. 1999.

40. WORLD HEALTH ORGANIZATION. Immunization Coverage. Geneva: WHO. 2015 